\title{
Fat mimetic capacity of Chlorella vulgaris biomass in oil-in-water food emulsions stabilized by pea protein
}

\author{
A. Raymundo $^{\text {a,* }}$, L. Gouveia ${ }^{\text {b }}$, A.P. Batista ${ }^{\text {a }}$, J. Empis ${ }^{\text {c }}$, I. Sousa ${ }^{\text {d }}$ \\ a Instituto Piaget, Centro de Investigação em Eng $\underline{a}$ Alimentar e Biotecnologia, ISEIT de Almada, Quinta da Arreinela de Cima, \\ 2800-305 Almada, Portugal \\ ${ }^{\mathrm{b}}$ Instituto Nacional de Engenharia e Tecnologia Industrial, INETI-DER, Unidade Biomassa, Estrada do Paço do Lumiar, 1649-038 Lisboa, Portugal

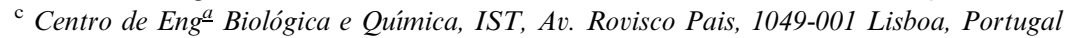 \\ d Seç̧ão de Ciência e Tecnologia dos Alimentos, Instituto Superior de Agronomia, Universidade Técnica de Lisboa, Tapada da Ajuda, \\ 1349-017 Lisboa, Portugal
}

Received 27 May 2004; accepted 25 February 2005

\begin{abstract}
Vegetable proteins proved to be good emulsifiers for food emulsions with dietetic advantages. The use of these emulsions as carriers for healthy ingredients, such as colourings, with antioxidant and other beneficial properties, is an interesting subject.

In this work, the capacity of the biomass of the microalga Chlorella vulgaris (which has been widely used as a food supplement) as a fat mimetic, and its emulsifier ability, was evaluated. Pea protein emulsions with C. vulgaris addition (both green and orange carotenogenic) were prepared at different protein and oil contents. The rheological properties of the respective food emulsions were measured in terms of the viscoelastic properties and steady state flow behaviour and texture properties. It was observed that the two microalgal forms evidenced a fat mimetic capacity in these emulsions, the performance of the green stage of this $C$. vulgaris organism was significantly $(p<0.05)$ better than the orange stage.
\end{abstract}

(c) 2005 Elsevier Ltd. All rights reserved.

Keywords: Emulsions; Rheology; Microalga; Fat-mimetic

\section{Introduction}

The use of microalgal biomass as an ingredient of oil/ water food emulsions has been recently investigated to act as a colouring agent (Gouveia et al., 2004). The addition of microalgal biomass to an emulsion system can produce different effects: either stability improvement through the development of cooperative effects with the pea protein or loss of surface viscoelasticity when it induces the displacement of the protein from the interface, as any other emulsion additive (Dickinson \& Hong, 1995).

\footnotetext{
${ }^{*}$ Corresponding author. Tel.: +351 21294 6269; fax: +351 21294 1584 .

E-mail address: araymundo@almada.ipiaget.org (A. Raymundo).
}

The production of "mayonnaises" and salad dressings (o/w emulsions) using vegetable emulsifiers to fully replace egg yolk has been extensively studied in the last few years (Franco, Raymundo, Sousa, \& Gallegos, 1998a; Raymundo, Franco, Gallegos, Empis, \& Sousa, 1998a), with several dietetic advantages. Furthermore, it was possible to produce low fat mayonnaise-like emulsions using xanthan gum to increase consistency, obtaining products with similar sensory characteristics (Raymundo, Nunes, Franco, Empis, \& Sousa, 2002). The addition of this type of polysaccharide affects the emulsion stability through viscosity modification of the aqueous phase and interactions with the protein films (Xie \& Hettiarachchy, 1997).

When a cooperative effect between the protein emulsifier and the microalgal components is observed, it can 
result on the reinforcement of the emulsion structure. The total oil content can be reduced in this case, yielding emulsions with the same rheological and sensory properties. For this reason it was considered that the biomass acted as a fat mimetic with a mechanism similar to xanthan.

\section{Materials and methods}

Chlorella vulgaris (INETI 58) - Cv was cultivated in a convenient growth medium (Vonshak, 1986); after growing in airlift bioreactors $C$. vulgaris (green) was recovered. Carotenogenesis was performed according to Gouveia et al. (1996) for Cv (orange). Microalgal biomass was harvested without flocculation, by simply removing agitation, concentration and subsequent freeze drying. The composition of these microalgae is (Gouveia, 1992):

$$
\begin{aligned}
\mathrm{Cv} \text { green }(\% \mathrm{w} 7 \mathrm{w}): \text { Carbohydrates }-18 ; \\
\text { Protein }-60 ; \text { Fat }-11 \text { and } \\
\text { Minerals }-2-5 \\
\mathrm{Cv} \text { orange }(\% \mathrm{w} 7 \mathrm{w}): \begin{array}{l}
\text { Carbohydrates }-30 ; \\
\text { Protein }-6 ; \text { Fat }-47 \text { and } \\
\text { Minerals }-2-5
\end{array}
\end{aligned}
$$

The emulsions were prepared by dissolving protein and microalga in distilled water with magnetic stirring for $30 \mathrm{~min}$, at room temperature $\left(20-22^{\circ} \mathrm{C}\right)$, followed by the addition of sunflower oil, under agitation in a Ultra Turrax T-25 rotor-stator homogenizer (Ika, Germany).

For the evaluation of microalgal fat mimetic effect, o/w emulsions with $3 \%$ of pea protein isolate (Pisane HD, Cosucra, Belgium) and $2 \%$ of C. vulgaris with oil concentration ranging from $50 \%$ up to $65 \%$ were prepared. The emulsifier capacity of the $C$. vulgaris was evaluated by preparing emulsions with no other emulsifier added, the various microalga biomass contents (2$5 \%$ ) being the only ingredient apart from water and oil.

The fat mimetic effect and the emulsifying properties of the microalgae were evaluated in terms of the emulsion's rheological properties, using a controlled stress rheometer (Haake-RS75, Germany). The mechanical spectra determined under linear viscoelastic behaviour were performed with a cone and plate system $\left(\mathrm{C} 35 / 1^{\circ}\right)$ and the Plateau modulus $\left(G_{N}^{0}\right)$ was the parameter used to compare emulsions. This parameter can be considered as a measure of the intensity of the entangled network developed between the adsorbed and not adsorbed protein molecules (Ferry, 1980; Franco, Berjano, \& Gallegos, 1997). Hence, $G_{N}^{0}$ can be estimated as the value of $G^{\prime}$ for the minimum of $\tan \delta(\mathrm{Wu}, 1989)$ :

$G_{N}^{0}=\left[G^{\prime}\right]_{\tan \delta \rightarrow \text { minimum }}$
For the steady state flow measurements, a rough surface parallel plate system was used, to overcome the slip effect (Franco, Gallegos, \& Barnes, 1998b). The comparison of the flow curves resulted from the adjustment of the Carreau model:

$\eta=\eta_{0} /\left[1+\left(\gamma^{*} / \gamma_{\mathrm{c}}\right)^{2}\right]^{s}$

where (i) $\eta_{0}$ is the zero shear rate limiting viscosity, i.e., the highest viscosity value the system can achieve at the same temperature; (ii) $\gamma_{c}$ is the critical shear rate for the onset of the shear-thinning behaviour; (iii) " $s$ " is a parameter related to the slope of the shear thinning region. The texture of the emulsions was objectively measured using a texturometer TA. XT Plus (SM Systems, UK) in penetration mode with a cylinder of $20 \mathrm{~mm}$ diameter probe plunged $5 \mathrm{~mm}$ at $2 \mathrm{~mm} / \mathrm{s}$, into emulsions contained in a $60 \mathrm{~mm}$ diameter glass flaks. Firmness, i.e., the resistance to penetration, was considered as the peak force in the texturogram in $N$.

\section{Results and discussion}

The effect of oil addition on the viscoelastic properties of the $3 \%$ pea emulsions with $2 \%$ of $C$. vulgaris (green and orange) can be observed in Fig. 1, in terms of the variation of the viscoelastic functions $\left(G^{\prime}\right.$ and $\left.G^{\prime \prime}\right)$ with frequency. These emulsions present mechanical spectra typical of protein-stabilized emulsions in which an elastic network develops due to the occurrence of an extensive bridging flocculation process (e.g., Franco et al., 1998a). Except for the emulsions with 50\% oil, the storage modulus $\left(G^{\prime}\right)$ was always larger than the loss modulus $\left(G^{\prime \prime}\right)$ in the frequency range studied, and the evolution of $G^{\prime}$ with frequency shows a tendency to the development of a plateau region, followed by a minimum in $G^{\prime \prime}$. The plateau modulus $\left(G_{N}^{0}\right)$ was studied as a characteristic parameter of this region.

From the dynamic measurements, it can be observed that, for a certain protein and microalgae concentration, higher oil content induces a reinforcement of the emulsion structure. This is demonstrated by the increase of the plateau modulus $\left(G_{N}^{0}\right)$. For the emulsion systems with addition of microalgal biomass, the $G_{N}^{0}$ value is significantly higher than for the standard. It is possible to produce emulsions with $55 \%$ oil that were more structured than the emulsions with $65 \%$ oil and no microalgal biomass addition. This result supports the potential use of using microalgae material to act as a fat mimetic, besides the possible advantages as colouring and antioxidant agent. This behaviour can be explained by the increase of the viscosity of the continuous phase of the emulsion, by the microalgal material, with a mechanism similar to that previously observed for xanthan gum (Raymundo et al., 2002; Xie \& Hettiarachchy, 1997). Possible interactions between pea protein and microal- 

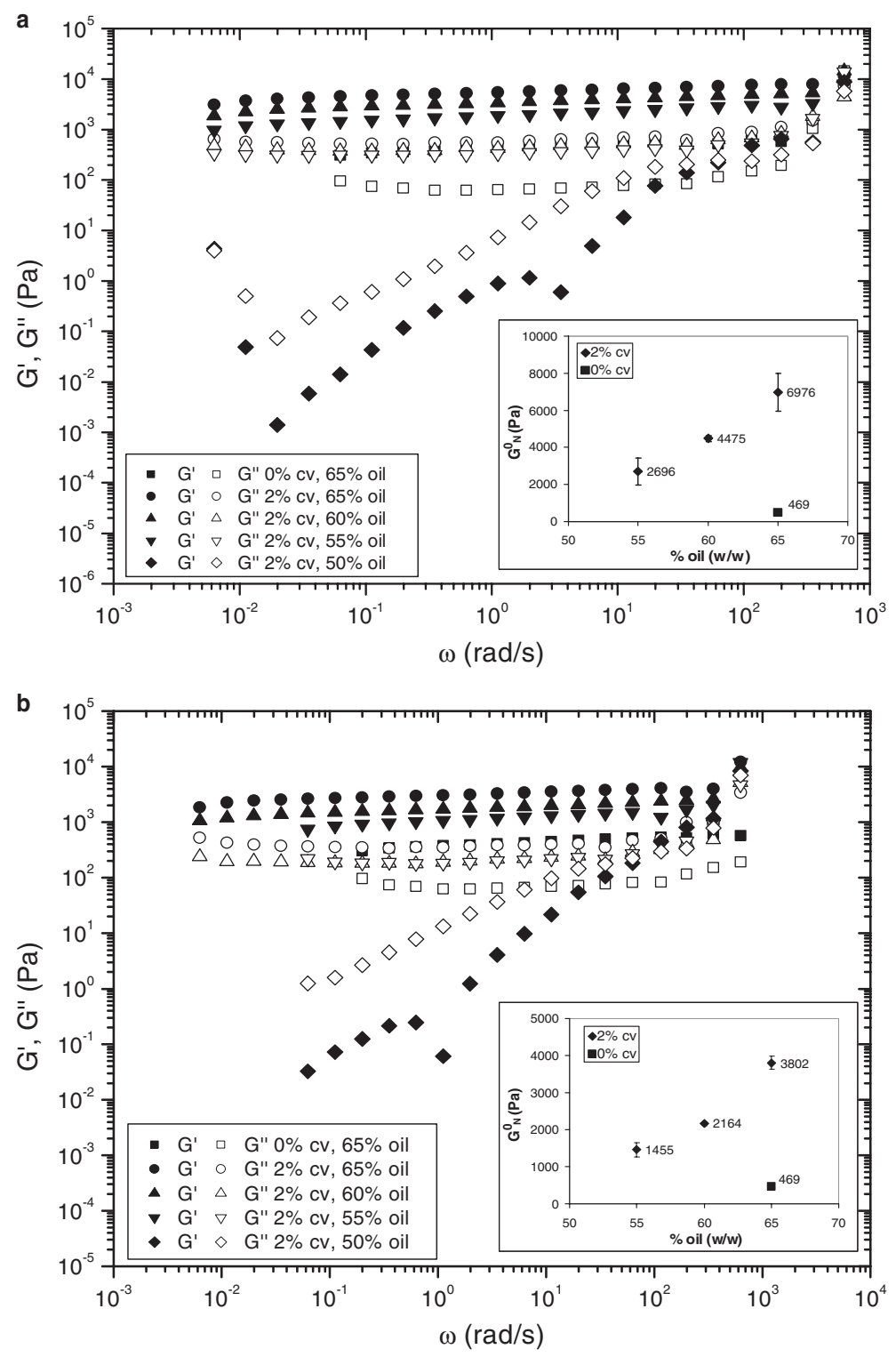

Fig. 1. Mechanical spectra of o/w emulsions with $3 \%$ pea protein and $2 \%$ of $\mathrm{Cv}$ orange (a) and $\mathrm{Cv}$ green (b) 2, for different oil content and respective values of $G_{N}^{0}$.

gal biomass can also contribute to the reinforcement of the emulsion structure through the formation of physical entanglements (Clark, Wilde, Wilson, \& Wustneck, 1992; Riscardo, Franco, \& Gallegos, 2003). This effect was more significant for $\mathrm{Cv}$ green a fact which must be related to its higher protein content $(60 \%$ for $\mathrm{CV}$ green against $6 \%$ for $\mathrm{Cv}$ orange).

Lessening oil content in these emulsions could not go beyond the $55 \%$ level. In fact, the preparations with $50 \%$ oil yielded a dispersion with no phase separation but an internal structure was not developed, which was expressed by the shape of the mechanical spectrum: $G^{\prime \prime}$ being higher than $G^{\prime}$, for the whole frequency range studied (Fig. 1).
The variation of the zero shear rate limiting viscosity versus oil content, obtained from the steady state flow measurements, according to the Eq. (2) (as in, e.g., Raymundo, Empis, \& Sousa, 1998b), with oil content, can be observed in Fig. 2. Although the protein of $\mathrm{Cv}$ orange is 10 times lower, the polysaccharide content will respond in terms of the viscosity increase of the aqueous media

The flow behaviour of these emulsions is in agreement with dynamic measurements, as $\eta_{0}$ increases with the increase of the oil content. This effect is more evident for the $\mathrm{Cv}$ green. Determinations under steady shear involve internal structure destruction as shear rate increases. The zero shear limiting viscosity represents the 


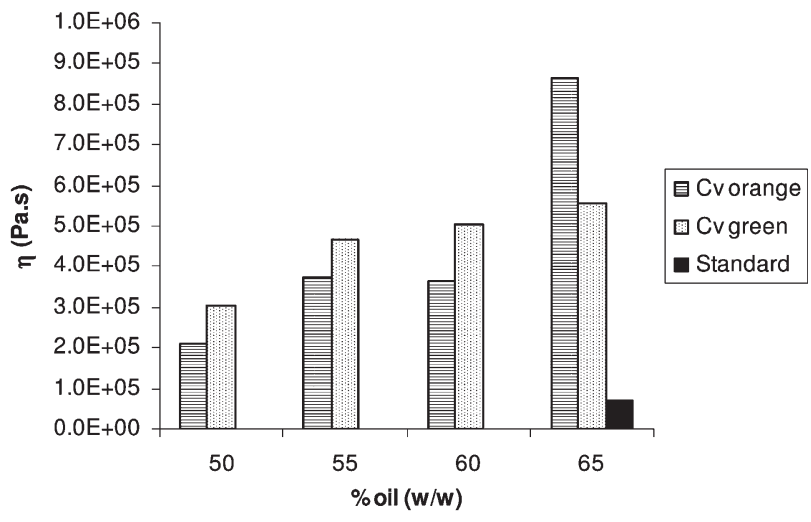

Fig. 2. Variation of zero shear rate limiting viscosity $\left(\eta_{0}\right)$ of o/w pea protein emulsions with $2 \%$ of $\mathrm{Cv}$ orange and $\mathrm{Cv}$ green, for different oil content and for a standard emulsion (no microalgal biomass addition).

viscosity, where the internal structure was not damaged by shear rate and in this sense, measures the highest resistance to flow of the system. Nevertheless, differences between $\mathrm{Cv}$ orange and $\mathrm{Cv}$ green are not so evident, and the same pattern of Fig. 1 for dynamic measurements applies. However, the suspension with $50 \%$ oil, which did not emulsify, evidenced compatible $\eta_{0}$ values. In this system even if the structure of an emulsion was not achieved, the flow was still difficult.

The same effect, i.e., a fat mimetic behaviour of the both microalgae, can be observed in terms of the textural properties of the emulsion, expressed in terms of firmness (Fig. 3).

However, texture does not differentiate between $\mathrm{Cv}$ green and $\mathrm{Cv}$ orange performance as fat mimetic, in both cases observed the exponential increase of firmness with oil contents was not significantly different. The suspension system, with no emulsion structure, shows values of firmness similar to those of the standard system.

When attempts to prepare emulsions without any protein addition were undertaken, i.e., using microalga as the sole emulsifier, a very unstable suspension was ob-

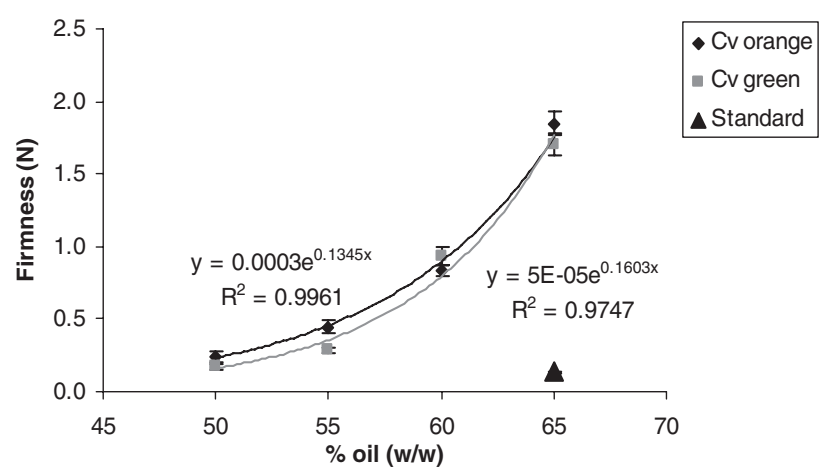

Fig. 3. Variation of firmness of o/w pea protein emulsions with $2 \%$ of $\mathrm{Cv}$ orange and $\mathrm{Cv}$ green, for different oil content and for a standard emulsion (no microalga addition). tained instead. The development of the emulsion structure did not occur when microalgal biomass fully replaced the vegetable protein as an emulsifier, and phase separation was instantaneous. This was not the case for the $50 \%$ oil, $3 \%$ protein and $2 \%$ microalgal previous suspension, which was very stable.

\section{Conclusions}

C. vulgaris biomass (green and orange) proved to impart a stable and appealing colour to food emulsions. The addition of this material proved to be beneficial in terms of enabling lesser oil contents for the emulsions, without disturbing their structural and texture properties. Although the microalgal biomass ( $\mathrm{Cv}$ green) has a high protein content, it cannot be used as only emulsifier in these types of emulsion systems.

\section{Acknowledgements}

The authors thank Eng. Manuel Resendes and Eng. Ana Miranda for technical support; Graça Conceição (INETI-DER) for microalgal biomass production; and Cosucra Groupe Warcoing (Belgium) for providing pea protein isolate samples.

\section{References}

Clark, D. C., Wilde, P. J., Wilson, D. R., \& Wustneck, R. (1992). The interaction of sucrose esters with $\beta$-lactoglobulin and $\alpha$-casein from bovine milk. Food Hydrocolloids, 6, 173-186.

Dickinson, E., \& Hong, S. T. (1995). Influence of water soluble nonionic emulsifier on the rheology of heat-set protein stabilized emulsions gels. Food Hydrocolloids, 43, 25-60.

Ferry, J. D. (1980). Viscoelastic properties of polymers (3rd ed.). New York: Wiley.

Franco, J. M., Berjano, M., \& Gallegos, C. (1997). Linear viscoelasticity of salad dressing emulsions. Journal of Agricultural and Food Chemistry, 45, 713-719.

Franco, J. M., Raymundo, A., Sousa, I., \& Gallegos, C. (1998a). Influence of processing variables on the rheological and textural roperties of lupin protein-stabilized emulsions. Journal of Agricultural and Food Chemistry, 46, 3109-3115.

Franco, J. M., Gallegos, C., \& Barnes, H. A. (1998b). On slip effects in steady-state flow measurements of oil-in-water food emulsions. Journal of Food Engineering, 36, 89-102.

Gouveia, L. (1992). Obtenção de biomassa microalgal e sua incorporação na cadeia alimentar. Master Thesis, UTL, Lisboa, p. $99 .$.

Gouveia, L., Veloso, V., Reis, A., Fernandes, H. L., Empis, J., \& Novais, J. M. (1996). Evolution of the pigments in Chlorella vulgaris during carotenogenesis. Bioresources Technology, 57, 157-163.

Gouveia, L., Raymundo, A., Batista, A. P., Miranda, A., Sousa, I., \& Empis, J. (2004). Coulouring emulsions using microbial biomass stability over time. In L. Dufossé (Ed.), Pigments in food-more than colours (pp. 121-123). Quimper: Pigments Publishing, Université de Bretagne Occidentale. 
Raymundo, A., Franco, J., Gallegos, C., Empis, J., \& Sousa, I. (1998a). Effect of thermal denaturation of lupin protein on its emulsifying properties. Nahrung, 42, 220-224.

Raymundo, A., Empis, J., \& Sousa, I. (1998b). Optimisation of lupin protein emulsion composition. Polish Journal of Nutritional Science, 7/48, 127-134.

Raymundo, A., Nunes, C., Franco, J., Empis, J., \& Sousa, I. (2002). Optimization of the composition of low-fat oil-in-water emulsions. Journal of American Oil and Chemistry Society, 79(8), 783-789.

Riscardo, M. A., Franco, J. A., \& Gallegos, C. (2003). Influence of composition of emulsifier blends on the rheological properties of salad dressing-type emulsions. Food Science and Technology International, 9(1), 53-63.

Vonshak, A. (1986). Laboratory techniques for the cultivation of microalgae. In A. Richmond (Ed.), CRC handbook of microalgal mass culture (pp. 117-143). Boca Raton, USA: CRC Press.

Wu, S. (1989). Chain structure and entanglement. Journal of Polymer Science, 27, 723-741.

Xie, Y. R., \& Hettiarachchy, N. S. (1997). Xanthan gum effects on solubility and emulsification properties of soy protein isolate. Journal of Food Science, 62, 1101-1104. 